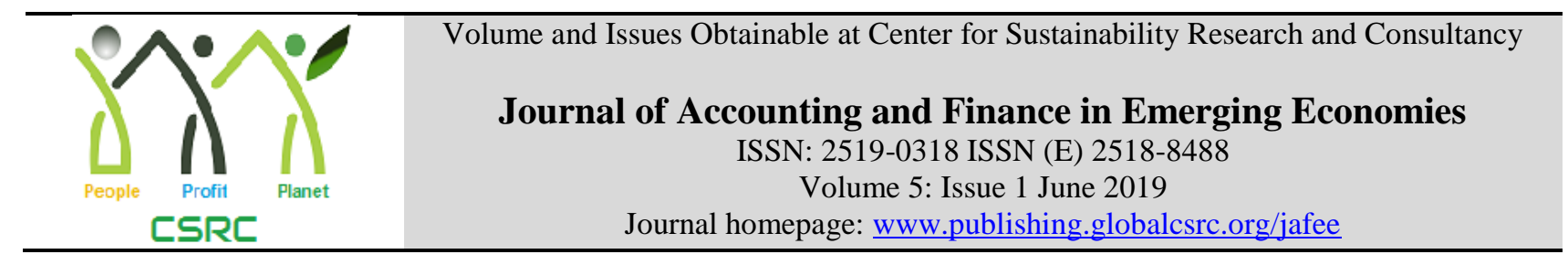

\title{
Impact of CSR on Financial Performance of Banks: A Case Study
}

\author{
${ }^{1}$ Sundas Memon, ${ }^{2}$ Waqar Sethar, ${ }^{3}$ Adnan Pitafi, ${ }^{4}$ Wasim Uddin \\ ${ }^{1}$ Research Scholar, Mehran University Institute of Science, Technology and Development Mehran University of \\ Engineering and Technology, Jamshoro, Sindh, Pakistan sundasmemon@gmail.com \\ ${ }^{2}$ Lecturer, Mehran University Institute of Science, Technology and Development Mehran University of Engineering \\ and Technology, Jamshoro, Sindh, Pakistan.waqar.sethar@faculty.muet.edu.pk \\ ${ }^{3}$ Assisstant Professor, Mehran University Institute of Science, Technology and Development Mehran University of \\ Engineering and Technology, Jamshoro, Sindh, Pakistan adnan.pitafi@ facultu.muet.edu.pk \\ ${ }^{4}$ Research Scholar, Department of management sciences, Comsat University Islamabad, \\ Pakistan.wasimkust@gmail.com
}

\begin{tabular}{l}
\multicolumn{1}{c}{ ARTICLE DETAILS } \\
\hline History \\
Revised format: May 2019 \\
Available Online: June 2019 \\
\\
\hline Keywords \\
Financial Performance, \\
Descriptive Analysis, Correlation \\
Analysis, Multiple Regression \\
Analysis, Econometric Models
\end{tabular}

JEL Classification:

P10,P17, P19, C50, C59

\begin{abstract}
The aim of current study is to investigate the impact of CSRRI on bank's financial performance. For this purpose, ROA, EPS and PAT are taken as proxies for measuring bank's financial performance by using time series and panel data. The time span is from 2004 to 2017 . The current study used HBL and MCB bank for analysis. The dependent variables are ROA, EPS and PAT while independent variables are CSRRI and bank size.

To estimate the model, the current study used quantitative data to analyse the results by using descriptive analysis, correlation analysis, and multiple regression analysis.

The findings of the current study revealed that the slope coefficient of intercept and CSRRI are positive except bank size which is negative in three models. In short, the CSRRI can

Further, CSR reporting may provide welfare for both banks and econometric models suggests that socially responsible banks can not only attract large numbers of customers but also increases profitability.
\end{abstract}

(C) 2019 The authors, under a Creative Commons Attribution-Non Commercial 4.0

Corresponding author's email address: sundasmemon@gmail.com

Recommended citation: Memon, S., Sethar, W., Pitafi, A. and Uddin, W. (2019). Impact of CSR on Financial Performance of Banks: A Case Study. Journal of Accounting and Finance in Emerging Economies, 5 (1), 129-140

DOI: $10.26710 /$ jafee.v5i1.366

\section{Introduction}

The possible emergence of corporate social responsibility (CSR) in the field of management takes place in 1950's in the United States. The socially responsible business operations in 1900 were in many forms such as philanthropic donations to charity, service to the community, upgrading wellbeing of workers and provide support to religious activities. The basis of CSR changed in 1980's from CSR to the obligations such as doing good to do good to the CSR as a strategy such as doing good to do well. (Banerjee, 2009). Pakistan has faced serious monetary challenges on national and global level because of enigmatic issues in governance, weak organizations, natural disasters, corrupt policies and practices of administration. Therefore, the problem of the institution exists, and the corporate governance is not developed. Although, companies are making money, but their contribution to society is limited. In Pakistan, the social sector has focused less on other sectors of the economy, such as education and health, in 
terms of investments made. Beyond that, there are differences in interest between company and the corporate sector, the issue of CSR has gone unnoticed which is not encouraging for the development of Pakistan (The Economic Survey of Pakistan, 2015). The key player in the Pakistani economy is considered to banking sector and vitalness of banks are not unnoticed because it has help out numerous people affected by floods and natural disasters (Malik, Ali and Ishfaq, 2015). In Pakistan, multinational companies such as Nestle and Unilever, have promulgated the idea of CSR, while banking companies such as HBL and MCB have begun to provide assistance in the preparation of talent and other contributions in education and health sector. Some firms are seeking and contributing to security regarding environment. There are few banks which are integrating the CSR with their objectives strategies and statements. The foundation of HBL also works for the society with objective of refining the value of life in Pakistan (Sustainability Report of HBL and MCB, 2011).

CSR is a new developing concept in Asia specifically in Pakistan. It has attained more interest in last few decades. The scope of corporate responsibility varies accordingly in different countries, regions, interest groups and organizations which includes not only environmental issues, but it also deals with other issues like; ethical, social, health, governance etc. Organizations are involved in more community development programs, health and other philanthropy activities to construct social and ethical image of their business. CSR has various definitions in corporate world. In line with Marrewijk (2003) who define the CSR is the solution which will resolve degradation in environment, poverty gap on international level, and social exclusion. It proves that almost all organizations try to show that their business does not stand only for profits, but they add some value to society with their activities which are for the benefit of society. The CSR requires that companies can acknowledge that they must be publicly accountable not only for their monetary performance, but also for their social and environmental record. More generally, the businesses can promote democracy, community improvement, human rights, and goals of sustainable growth on international level are included in CSR related activities (CBI, 2001a). Helg (2007) stated that firms should standardized CSR activities in order to make its impact on society.

The socially responsible firms have positive impact on their reputation. The customers are demanding from organizations to behave ethically and socially because they have become more concern about social obligations and are demanding environment friendly products. The understanding of environmental issues to the public over the past few years has increased, and it is necessary for firms to take this in consideration since the customers have ability to harm the brand tremendously. (Walker et al., 2008). Many firms in Pakistan are playing vital role in implementation of environmental growth and social well-being. For e.g. Oil \& gas companies have invested in poor and local communities and build schools and hospitals. Banking, Automobile and other business sectors have also engaged themselves in environmental protection measures, energy conservations, sports and other good governance activities. CSR has shown a great impact in today's world by maintaining both financial growth and social responsibility. There is a vast literature present on CSR since two decades. But, the research shows that still a controversial data is present on both the financial growth of a firm and performance of CSR (Alshammari, 2015).

The traditional view is presented by Friedman (1970). He stated that firm's that are social responsible in order to earn returns. In addition, such firms are using its own resources and involve in those activities which are designed to raise returns and are also engage in free and open competition without fraud or dishonesty (The New York Times Magazine, 1970). While Carroll (1991) believed that the purpose of business is not only involved in profit maximization. During 1991, he introduced a pyramid of responsibilities which give clear understanding of corporate social responsibility. The concept behind CSR is that businesses should do more than just making profits. They should engage themselves in activities that benefit society and environment. Carroll's four layered pyramid well explains the corporate social responsibility. The four layers of pyramid are economical, legal, ethical and philanthropic. 


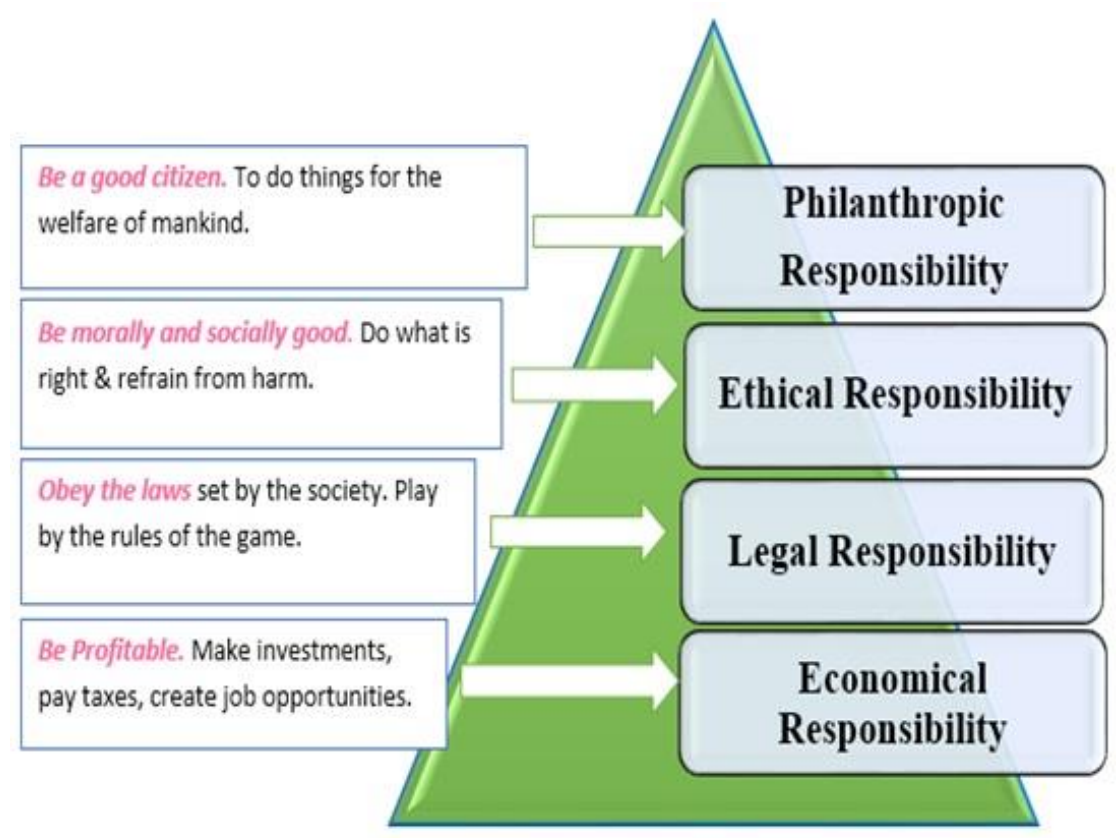

\section{Fig. 1. Carroll's Pyramid}

Source: https://research-methodology.net/carrolls-csr-pyramid-and-its-applications-to-small-and-medium-sizedbusinesses/

Being profitable is the first and foremost obligation of any business. This is the basis of rest of the responsibilities. The second responsibility is being legal which means businesses should abide by laws which are established by the society. The third responsibility is ethical responsibility. Being ethical means what is right and whenever laws don't allow businesses to do unethical practices. The fourth responsibility is philanthropic which are mainly include welfare of human beings and to spread the goodwill. The objective of this article is to investigate the impact of CSR activities on financial performance of both banks in Pakistan based on descriptive analysis, correlation analysis and regression analysis. This article is divided into five sections. The second section is about literature review, the third section is about data and methodology. The fourth section is about results and discussions and last section is conclusion.

\section{Literature Review}

Having idea of CSR activities, the following is the empirical literature survey examined in this paper. CSR is one of obligations of corporations to its stakeholder and furthermore a willful obligation by organization to sustainable progression (Crane and Matten, 2007). During era of expanding the corporate monetary outrages, CSR has shift to essential methodology for firms globally in order to enhance the image of CSR related activities and such practices can conceivably make a brand image for firms and can create the positive linkages among stakeholders (Yoon, Gürhan-Canli and Schwarz, 2006). CSR might be referred as corporate citizenship and can mainly involve in short term costs that ae unable to provide a quick monetary advantage to businesses, but instead can promote the positive change in society and environment. The term is mostly put on organization's activities which are essential by controllers or environmentalist assurance groups. The ongoing demanding firms in eras of globalization are more engage in the CSR related activities (Chapple and Moon, 2005).

Soana (2011) studied the connection between corporate financial performance (CFP) and corporate social performance (CSP) in banks. Since 1970's, Anglo-American examinations have explored the topic of CSR. Various work done by researchers have concentrated on the examinations of conceivable expenses and advantages that would result from the usage of socially responsible activities keeping in mind the end goal to comprehend whether such activities involve economic and monetary loss or despite what might be expected, regardless of whether they ensure the accomplishment of competitive advantage. To this point, various quantitative examinations have been completed to set up, to a great extent in testing different businesses and the link between CSP and CFP. Such investigations delivered opposing outcomes and any endeavor to give a summed up and coherent conclusion that has demonstrated inappropriate. The point of their examination is to research the conceivable connection between social execution and money related execution in banking sector. In example of national and global banks, the 
possible link between social execution and money related financial execution has been analyzed. It rises up out of these investigations that there is insignificant link which can demonstrates any positive / negative relationship between CSP and CFP.

Mahbuba and Farzana (2013) studied the CSR and profitability based on case study by using Dutch Bangla Bank Limited (DBBL) during period from 2002 to 2011. The magnificent history of Bangladeshi banks is involved themselves in diverse types of social actions which is previously called as CSR. The objective of their study is to examine the association between CSR and profitability. The methodology is regression analysis based on Ordinary Least Square (OLS) for analyze and estimate the model. The result shows that 90.70 percent of variations of profit after taxes (PAT) of DBBL has been explained by advantages accrued from CSR. In addition, there is positive and significant link between CSR and PAT.

Malik and Nadeem (2014) examined the impact of CSR on the monetary performance of banks in Pakistan during period from 2008 to 2012. The data is collected from yearly financial statements of banks. The endogenous variables are EPS, ROE, ROA and total Profit while exogenous variable is CSR. The methodology is based on regression analysis. The results reveal that there is lack of CSR in Pakistan. In addition, the result also reveals a positive link between bank's profitability (i.e. EPS, ROE, ROA and total Profit) and CSR activities. The banks which are implementing CSR activities in their operations can earn more return during large period.

Djalilov et al., (2014) studied the CSR performance of banks in transition states. The objective of their study is to investigate the nature of association between CSR and performance of banks and the motive of banking sector to engage in CSR related activities. The other objective includes whether this is dissimilar during stable periods i.e. 2002 to 2005 and turbulent periods i.e. 2008 to 2012. They used 16 transition states of Central and Eastern Europe and former Soviet Union. The results of the structural equation model using the data for 254 banks show that there is a positive impact of bank performance on CSR activities in stable and turbulent periods which point toward the strategic choice that is a foremost reason for banking sector in order to engage in CSR related activities. Chang and Shen (2014) studied the CSR and firm's profitability in Taiwan Stock Exchange during period from 2005 to 2009. They examine two problems related to CSR related and the firm's cost of debt which is taken as proxy for credit ratings. First, we investigate whether CSR activities has a positive effect on credit ratings and thus decreases the cost of debt. Second, they studied the credit ratings is taken as mediator between CSR and profitability of firms. The mediator here means that, given the presence of credit ratings, the impacts of CSR on the firm's performance will be lower than in those cases where credit ratings are not considered in the regression analysis. The results reveal that firms engage in CSR activities tend to have higher creditworthiness and thus a lesser cost of debt. Moreover, after controlling for credit ratings, the impact of the CSR activities on the profitability of firm is reduced, thereby showing that credit ratings serve as the mediator between CSR and performance.

Malik, Ali and Ishfaq (2015) studied the CSR activities and organizational performance by using banking sector. Numerous work done in past to investigate link between corporate sustainability, CSR and business performance. The study is based on exploratory research. They used both primary and secondary data. The primary data of employees of banks collected while secondary data were collected from articles, financial statements. The methodology s based on correlation and regression analysis. The study found link between awareness of CSR activities and organizational performance. In addition, the study found linkage between organizational performance and organizational culture for the banking sector of Pakistan. The results also reveal a significant impact for Pakistani banks.

Arshad, Anees and Ullah (2015) studied the impact of CSR on the monetary performance of firms during period from 2009 to 2013. CSR is the summation of donation and environmental cost which is taken from financial statements of firms. The monetary performance of the firms is measured as ROA and Tobin's Q. The sample size is based on 125 firms which are listed in Karachi stock exchange in Pakistan. The companies which selected for sample purpose are taken from 25 sectors. The methodology is based on regression analysis. The results reveal that there is no significant impact of CSR on the financial performance in short-term scenario at 5 percent confidence level but found positive impact at 10 percent confidence value. In long-term scenario, CSR has no impact on Tobin's Q for the selected companies. The study has documented recommendation for policy makers as CSR activities in Pakistan is a new phenomenon. 
Nidhi (2016) studied the CSR in banking industry of India. They stated that CSR is mainly refer what a business are doing over and above legal obligation for the advantage of humanity. The word responsibility emphasizes on business that has few moral commitments towards humanity. Now-a-days CSR has been assuming greater importance in the corporate world including financial institutions and banking sector. Banks and other monetary institutions are starting to promote the socially responsible lending and environment friendly investment practices. The sample size is six banks based on secondary data. Further, the author also used a case study on HDFC Bank.

Bagh et al., (2017) studied the CSR and monetary performance of by using financial sector of Pakistan. The competitiveness of monetary sector has enlarged manifold and the issue of CSR has become an indispensable concern parallel to concentrating on profitability enhancement. The businesses are mainly considering as social units, to serve stakeholders. Such business can tend to implement CSR on significance basis and subsequent disclosure as well. Unhealthy CSR policies may cause externalities and eventual resigned clients. The aim of their study is to emphasis on impact of CSR on monetary performance of banking sector of Pakistan, using a sample of thirty banks listed on PSX during 2006 to 2015. The methodology is based on pooled regression models. The findings signify the robustness of pooled model that documented a positive and significant impact of CSR on ROA, ROE and EPS. This premise holds that CSR has positive and significant impact on financial performance of carefully chosen commercial banks of Pakistan. The findings reveal that CSR phenomena is considering as a vital growth element and monetary performance is boosting tool by banking sector of Pakistan. Finally, majority of the studies on CSR are in context of well-established firms and states. However, emerging states are least highlighted.

Alshehhi, Nobanee and Khare (2018) studied the effect of sustainability practices on corporate financial performance. The connection between corporate sustainable practices and financial performance has received rising attention in past work but an agreement remains indescribable. This paper mainly identifies by developing trends and enigmatic problem that can hinder the conclusive consensus in such linkage. The methodology is based on content analysis. An aggregate of one hundred and thirty-two papers from top-level journals are selected. We find that 78 percent of publications report have a positive link between corporate sustainability and financial performance. There are variations in research methodology and measurement of variables lead to the opposing view on such linkage. But besides this, past work is gradually supplanting total sustainability with narrow CSR which is dominated by the social measurement of sustainability while incorporating little to nothing of natural and financial measurements. The past work from developing states remains rare.

In short, the literature scrutinizes that the crucial of CSR and firm's profitability in Pakistani banks are not explored during period of 14 years i.e. 2004 to 2017 . There is a requirement of such study to inspect the impact of CSR activities on firm's profitability. This study tries to fill the gap in academic research using three models based on panel data and various techniques such as descriptive and correlation analysis, and multiple regression analysis.

\section{Methodology}

The current paper is based on secondary data which is collected form financial reports of HBL and MCB during period from 2004 to 2017. It includes all those commercial banks of Pakistan that are listed in Pakistan Stock Exchange (PSX) during 2004-2017.

The sample size of this study is based on two commercial banks i.e. HBL and MCB.

\subsection{Method}

This section makes clear the methods and tests that will be used for the empirical analysis. A time series and panel data set are used, since earlier work done by previous scholars on the impact of CSR reporting index on ROA (Mahbuba and Farzana, 2013). There are three models used in the current study based on OLS regression by using panel data. In addition, descriptive analysis, correlation matrix and regression analysis are used to estimate the model (Mahbuba and Farzana, 2013; Malik, Ali and Ishfaq, 2015).

\subsection{Variables Measurement and Definitions}

3.2.1 Return on Asset (ROA)

It is an endogenous variable of the current study and taken as proxy for financial performance that is used as a proxy for the profitability of banks (Shoukat and Nadeem, 2014; Malik and Nadeem, 2014). It can measure to estimate the monetary strength and efficiency of business in terms of operating the available financial resources (Bagh, et al., 2017). Mathematically, the ROA can be calculated as: 


$$
\mathrm{ROA}=\frac{\text { Net Profit After Interest and Taxes }}{\text { Total Assets }}
$$

\subsubsection{Earnings Per Share (EPS)}

It is an endogenous variable and a measure of financial performance. It shows the earnings of banks' in terms of how more return is earned on behalf of each outstanding share of common stock during period of one year (Malik and Nadeem, 2014). Mathematically, the EPS can be calculated as:

$$
\mathrm{EPS}=\frac{\text { Net Profit After Interest and Taxes }}{\text { Total No.of Outstanding Share of Common Stock }}
$$

\subsubsection{Profit after Taxes (PAT)}

It is an endogenous variable and a measure of financial performance. It shows the calculated by dividing net profit after interest and taxes by total revenue of bank. Mathematically, the PAT can be calculated as:

$$
\text { PAT }=\frac{\text { Net Profit After after Interest and Taxes }}{\text { Total Revenue }}
$$

\subsubsection{Corporate Social Responsibility Reporting Index (CSRRI)}

It is explanatory variable of current study. CSR is known as corporate conscience or responsible businesses is a form of corporate self-regulation integrated into a business model (Nidhi, 2016). In other words, CSR is evaluated by using the investment made in CSR like education, health, donation, social good and other expected disasters for CSR activities in reports regarding banks under study (Shoukat and Nadeem, 2014; Murtaza, 2014; Malik and Nadeem, 2014). There are some major CSR related activities which are specified by Rashid and Sharif (2013) that can mainly contributes to education sector, support to health sector, activities for donations, natural disaster, accomplishments for staffs, ecological problems, and services and products. The CSRRI can be calculated as follows (Sharif and Rashid, 2013).

$$
\operatorname{CSRRI}=\sum \frac{\mathrm{di}}{\mathrm{nj}}
$$

Where,

$\mathrm{di}=1$, if the item di is disclosed and 0 if the item di is not disclosed,

$n j=$ Highest number of items for $j$ th firms and $n j \leq 60$

To calculate a particular firm score, each item scores added are totally divided by the highest likely score multiplied by 100 to get the percentage scores. In this study, sixty items of CSR activities represent the highest probable reporting score. (Sharif and Rashid, 2013).

\subsubsection{Bank Size (BS)}

It is control variable of current study. Different proxies are being used by the researcher in order to measure the firm size. For example, natural log of sales, market capitalization and net assets. In current study, size of bank is calculated by taking natural logarithm of total assets. Mathematically, we can write as:

$$
\mathrm{BS}=\ln \text { (Total Assets) }
$$

Where, $\ln =$ Natural Logarithm

\subsection{Econometric Model}

The following three econometric models are used to estimate the multiple linear regression model based on panel data.

$$
\begin{aligned}
& \text { ROA it }=\alpha_{0}+\beta 1 \text { CSRRI it }+\beta 2 \text { BS it }+\epsilon \text { it } \\
& \text { EPS it }=\alpha_{0}+\beta 1 \text { CSRRI it }+\beta 2 \text { BS it }+\epsilon \text { it } \\
& \text { PAT it }=\alpha_{0}+\beta 1 \text { CSRRI it }+\beta 2 \text { BS it }+\epsilon \text { it }
\end{aligned}
$$


Where,

$$
\begin{aligned}
& \alpha_{0} \quad=\text { Intercept } \\
& \beta 1=\text { Slope coefficients of CSRRI. } \\
& \beta 2=\text { Slope coefficients of Bank Size. } \\
& \text { ROAit }=\text { Rerun of Asset of ith bank in year } \mathrm{t} \text {. } \\
& \text { EPSit }=\text { Earnings per Share of ith bank in year } \mathrm{t} \text {. } \\
& \text { PATit }=\text { Profit after Taxes of ith bank in year } \mathrm{t} \text {. } \\
& \text { CSRRIit = Explanatory variable and stands for corporate social responsibility reporting index of ith bank in year } \\
& \text { BSit = Bank Size of ith bank in year } \mathrm{t} \text {. } \\
& \text { eit }=\text { Error term of ith in year } \mathrm{t} \text {. } \\
& \mathrm{i}=1, \ldots \ldots, 2 \text { i.e. banks } \\
& \mathrm{t}=1, \ldots \ldots, 14 \text { i.e. years }
\end{aligned}
$$

\section{Results and Discussion}

The below table 4.1 shows the descriptive analysis of all the variables used in the current study which include mean, median, standard deviation (SD) and observation.

Table 4.1: Descriptive Statistics

\begin{tabular}{lccccc}
\hline Measures & Mean & SD & Min & Max & Observation \\
\hline ROA & 2.5646 & 1.6011 & 0.3000 & 7.3300 & 28 \\
EPS & 21.5447 & 9.1922 & 5.5780 & 42.7635 & 28 \\
PAT & 40.6963 & 13.7177 & 7.0492 & 65.8421 & 28 \\
CSRRI & 0.2030 & 0.0991 & 0.0833 & 0.3167 & 28 \\
Bank Size & 27.4323 & 0.6349 & 26.2812 & 28.6184 & 28 \\
\hline
\end{tabular}

The mean value of ROA regarding HBL and MCB is $2.5646 \%$ shown in Table 4.1. The variability in data regarding ROA is measured by SD that is $1.6011 \%$ for HBL and MCB during period from 2004 to 2017. It is quite lower and is a signal of less risk. Furthermore, the higher value of ROA is the indication of high profitability of both banks. The value of ROA fluctuates between $0.3000 \%$ and $7.3300 \%$. The average value of EPS is $21.5447 \%$. The variability in data regarding EPS is higher from all variables except PAT which is $9.1922 \%$ for both banks during period from 2004 to 2017. The value of EPS fluctuates between $5.5780 \%$ and $42.7635 \%$. The mean value of PAT is $40.6963 \%$. The variability in data regarding PAT is highest as compared to other variables which is $13.7177 \%$ for both banks during period from 2004 to 2017 . The minimum value of PAT is $7.0492 \%$ and maximum value of PAT is $65.8421 \%$. The mean value of CSRRI is $0.2030 \%$. The variability around means value is measured by standard deviations which is lowest for CSRRI i.e. $0.0991 \%$ for both banks from $2004-2017$. The value of CSRRI ranges between $0.083 \%$ and $0.3167 \%$ which is good signal in order to maintain CSRRI in both banks during period from 2014-2017. The average value of bank size is $27.4323 \%$. The variability around mean value is measured by standard deviations which is $0.6349 \%$ and greater than CSRRI. The value of bank size fluctuates between $26.2812 \%$ and $28.6184 \%$ which is good signal in order to maintain high value of investments for investors in terms of total assets in balance sheet by both banks during period from 2014 to 2017. 
The correlation analysis of all variables used in current study is shown in Table 4.2. Correlation measures the degree or strength of relationship among the variables. It ranges from minus one to plus one. Minus one shows a strong negative correlation, while plus one shows strong positive correlation. The correlation equal or less than 0.25 is considered as weak, whereas, if the degree of correlation between exogenous variables is 0.80 or more, there will be the problem of multicollinearity.

\begin{tabular}{lccccc}
\multicolumn{6}{l}{ Table 4.2: Correlation Matrix } \\
Variables & ROA & EPS & PAT & CSRRI & Bank Size \\
\hline ROA & 1.0000 & & & & \\
EPS & 0.8946 & 1.0000 & & & \\
PAT & 0.7962 & 0.8330 & 1.0000 & & \\
CSRRI & 0.5560 & 0.5469 & 0.6331 & 1.0000 & \\
Bank Size & -0.4963 & -0.1617 & -0.4211 & -0.2815 & 1.0000 \\
\hline
\end{tabular}

The result of correlation matrix is shown in Table 4.2. It is clear form correlation matrix that there is no problem of multicollinearity found in dependent and independent variables. In fact, there is high multicollinearity found among dependent variables i.e. ROA, EPS and PAT. In addition, we are not interested in correlation among dependent variables. All the variables correlation is less than $80 \%$. The slightly strong and positive correlation is found between PAT and CSRRI which is $63.31 \%$ while moderate and positive correlation is found between ROA and CSRRI and EPS and CSRRI which is 55.60\% and 54.69\%, respectively. The moderate and negative correlation is found between ROA and bank size which is $-49.63 \%$. The lowest negative correlation is found between EPS and banks size which is $-16.17 \%$. Thus, the correlation value fluctuates between $63.31 \%$ and $-49.63 \%$. Furthermore, the linear association between endogenous and exogenous variables are analyze by regression analysis which will show better results because regression analysis is more flexible and accurate than correlation. The result of the multiple linear regression model of the current study are shown in Table 4.3, 4.4 and 4.5, respectively by using three dependent variables i.e. ROA, EPS and PAT.

Table 4.3: Regression Results of Model-1

\begin{tabular}{lcccc}
\hline Variables & Coefficient & Std. Error & t-stat & P-Value \\
\hline Intercept & 26.6085 & 11.0007 & 2.4200 & $0.0230^{* *}$ \\
CSRRI & 7.3061 & 2.5329 & 2.8800 & $0.0080^{*}$ \\
Bank Size & -0.9305 & 0.3952 & -2.3500 & $0.0270^{* *}$ \\
\hline
\end{tabular}

$\mathrm{N}=28, \mathrm{R}=65.92 \%, \mathrm{R}^{2}=43.45 \%, \mathrm{~F}$-stat $=9.60$, Prob. (F-stat) $=0.0008$

Where $* * *$ and $* * *$ indicates the level of significance at 1,5 and 10 percent.

It is clear from Table 4.3 that the slope coefficient of intercept and CSRRI are positive except bank size which is negative. The coefficient of correlation is $65.92 \%$ which shows a slightly strong and positive link found between ROA and independent variables. The coefficient of determination (R2) is $43.46 \%$ which means that the $43.46 \%$ variations in ROA are explained by CSRRI and bank size. The probability of F-stat is $0.08 \%$ which is less than 5\% level of significance. Thus, it can support the validity, usefulness and statistically significant of model. The below Eq. (4.1) is the numerical form of multiple linear regression model.

$$
\text { ROAit }=26.6085+7.3061 \text { CSRRI }-0.9305 \text { Bank Size }+\epsilon i t
$$


It is clear from the above Eq. (4.1) that the slope of equation is positive and significant at $5 \%$ because P-value of intercept is $2.30 \%$ which is less than $5 \%$ level of significance. In addition, intercept is positive which means that when all determinants of ROA are zero then ROA will be positive which is 26.6085. The slope coefficient of CSRRI is positive and statistically significant at $1 \%$. If one-unit increase in CSSRI then ROA bill be increased by 7.3061 units. The slope coefficient of bank size is negative and significant at 5\%. If one-unit increase in bank size, then ROA will be reduced by 0.9305 units.

Table 4.4: Regression Results of Model-2

\begin{tabular}{|c|c|c|c|c|}
\hline Variables & Coefficient & Std. Error & t-stat & P -Value \\
\hline Intercept & 14.6310 & 70.3086 & -1.0100 & 0.8370 \\
\hline CSRRI & 50.5247 & 16.1887 & 0.2600 & $0.0050 *$ \\
\hline Bank Size & -0.1281 & 2.5261 & 1.2100 & 0.9620 \\
\hline
\end{tabular}

The slope coefficient of intercept and CSSRI is positive while slope coefficient of bank size is negative shown in Table 4.4. The coefficient of correlation is $54.70 \%$ which shows a slightly weak and positive link found between EPS and independent variables. The coefficient of determination (R2) is $29.92 \%$ which means that the $29.92 \%$ variations in EPS are explained by CSRRI and bank size. The probability of F-stat is $1.17 \%$ which is less than 5\% level of significance. Thus, it can support the validity, usefulness and statistically significant of model. The below Eq. (4.2) is the numerical form of multiple linear regression model.

EPSit $=14.6310+50.5247$ CSRRI -0.1281 Bank Size + eit

It is clear from the above Eq. (4.2) that the slope of equation is positive and statistically insignificant at 5\% because $\mathrm{P}$-value of intercept is $83.70 \%$ which is greater than $5 \%$ level of significance. In addition, intercept is positive which means that when all determinants of EPS are zero then EPS will be positive which is 14.6310. The slope coefficient of CSRRI is positive and statistically significant 5\%. If one-unit increase in CSSRI then EPS will be increased by 50.5247 units. The slope coefficient of bank size is negative and statistically insignificant. If one-unit increase in bank size, then EPS will be reduced by 0.1281 units.

Table 4.5: Regression Results of Model-3

\begin{tabular}{lcccc}
\hline Variables & Coefficient & Std. Error & t-stat & P -Value \\
\hline Intercept & 181.3068 & 91.6881 & 1.9800 & $0.0590^{* * * *}$ \\
CSRRI & 77.3749 & 21.1114 & 3.6700 & $0.0010^{*}$ \\
Bank Size & -5.6982 & 3.2942 & -1.7300 & $0.0960^{* * *}$ \\
\hline
\end{tabular}

$\mathrm{N}=28, \mathrm{R}=68.17 \%, \mathrm{R}^{2}=46.48 \%, \mathrm{~F}$-stat $=10.86$, Prob. $(\mathrm{F}$-stat $)=0.0004$

Where $*, * *$ and $* * *$ indicates the level of significance at 1,5 and 10 percent. 
The slope coefficient of intercept and CSRRI are positive except bank size which is negative shown in Table 4.5. The coefficient of correlation is $68.17 \%$ which shows a slightly strong and positive link found between PAT and exogenous variables. The $\mathrm{R} 2$ is $46.48 \%$ which means that the $46.48 \%$ variations in PAT are explained by CSRRI and bank size. The probability of F-stat is $0.04 \%$ which is less than $5 \%$ level of significance. Thus, it can support the validity, usefulness and statistically significant of model. The below Eq. (4.3) is the numerical form of regression model.

$$
\text { PATit }=181.3068+77.3749 \text { CSRRI }-5.6992 \text { Bank Size }+\epsilon i t
$$

The intercept of model-3 is positive and significant at $10 \%$ because P-value of intercept is $5.9 \%$ which is greater than 5\% level of significance shown in Eq. (4.3). In addition, intercept is positive which means that when all determinants of PAT are zero then PAT will be positive which is 181.3068. The slope coefficient of CSRRI is positive and statistically significant at 5\%. If one-unit increase in CSSRI then PAT will increase by 77.3749 units. The slope coefficient of bank size is negative and significant at $10 \%$ because P-value is $9.60 \%$ which is lower than $10 \%$ level of significance. If one-unit increase in bank size, then PAT will be reduced by 5.6992 .

\section{Conclusion}

The aim of this study is to investigate the impact of CSRRI on banks financial performance. For this purpose, ROA, EPS and PAT are taken as proxies for measuring bank's financial performance by using panel data. The time span is from 2004 to 2017 by using two banks i.e. HBL and MCB. The dependent variables are ROA, EPS and PAT while independent variables are CSRRI and bank size. There are 3 models used in current study based on panel data. To estimate the model, the current study used descriptive analysis, correlation analysis and multiple regression models. The result reveals that all models can support the validity, and significant at 5\% as per lower P-value of Fstat. The findings of current study revealed that slope coefficient of intercept and CSRRI are positive except bank size which is negative in model-1, model-2 and mode-3. The coefficient of correlation (R) of three models are $65.92 \%, 54.70 \%$ and $68.17 \%$, respectively. The coefficient of determination (R2) of all three models are $43.45 \%$, $29.92 \%$ and $46.48 \%$, respectively. Overall, the CSRRI can significantly and positively impacting the profitability. CSR reporting may provide assistances and welfares for both banks and the econometric models suggests that socially responsible banks can not only attract large numbers of customers but also increases profitability.

\section{References}

Alshammari, M. (2015). Corporate social responsibility and firm performance: The moderating role of reputation and institutional investors. International Journal of Business and Management, 10(6), 15

Alshehhi, A., Nobanee, H., \& Khare, N. (2018). The impact of sustainability practices on corporate financial performance: Literature trends and future research potential. Sustainability, 10(2), 494.

Arshad, M. G., Anees, F., \& Ullah, M. R. (2015) the impact of corporate social responsibility on firm's financial performance. The International Journal of Applied Research, 4, 9-28

Bagh, T., Khan, M. A., Azad, T., Saddique, S., \& Khan, M. A. (2017). The Corporate Social Responsibility and Firms' Financial Performance: Evidence from Financial Sector of Pakistan. International Journal of Economics and Financial Issues, 7(2), 301-308.

Banerjee, S. B. (2008). Corporate social responsibility: The good, the bad and the ugly. Critical sociology, 34(1), 51-79.

Carroll, A. B. (1991). The pyramid of corporate social responsibility: Toward the moral management of organizational stakeholders. Business horizons, 34(4), 39-48.

Chang, Y., \& Shen, C. H. (2014). Corporate social responsibility and profitability-Cost of debt as the mediator. Taipei Economic Inquiry, 50(2), 291.

Chapple, W., \& Moon, J. (2005). Corporate social responsibility (CSR) in Asia: A seven-country study of CSR web site reporting. Business \& society, 44(4), 415-441.

Confederation of British Industry (2001a) Issue statement: Corporate Social responsibility. Retrieved from http://www.cbi.org.uk/home.html

Djalilov, K., Vasylieva, T. A., Lieonov, S. V., \& Lasukova, A. S. (2014). Corporate social responsibility and bank performance in transition countries (Doctoral dissertation, Українська академія банківської справи Національного банку України). Friedman, М. (1970) the social responsibility of business is to increase its 
profits. New York Times Magazine, 32-33, 122-124.

Helg, Å. (2007). Corporate social responsibility from a Nigerian perspective. rapport nr.: Organisation.

Mahbuba, S., \& Farzana, N. (2013). Corporate Social Responsibility and Profitability: A Case Study on Dutch Bangla Bank Ltd. International Journal of Business and Social Research, 3(4), 139-145.

Malik, M. S., \& Nadeem, M. (2014). Impact of corporate social responsibility on the financial performance of banks in Pakistan. International Letters of Social and Humanistic Sciences, 10(1), 9-19.

Malik, M. S., Ali, H., \& Ishfaq, A. (2015). Corporate social responsibility and organizational performance: Empirical evidence from banking sector. Pakistan Journal of Commerce and Social Sciences, 9(1), 241. Van Marrewijk, M. (2003). Concepts and definitions of CSR and corporate sustainability: Between agency and communion. Journal of business ethics, 44(2-3), 95-105.

Nidhi (2016) corporate social responsibility in Indian banking industry: study on attempts of HDFC bank. International Journal of Research, 4(8), 62-74.

Sharif, M., \& Rashid, K. (2014). Corporate governance and corporate social responsibility (CSR) reporting: an empirical evidence from commercial banks (CB) of Pakistan. Quality \& Quantity, 48(5), 2501-2521.

Soana, M. G. (2011). The relationship between corporate social performance and corporate financial performance in the banking sector. Journal of business ethics, 104(1), 133.

Walker, H. L., Gough, S., Bakker, E. F., Knight, L. A., \& McBain, D. (2009). Greening operations management: An online sustainable procurement course for practitioners. Journal of Management Education, 33(3), 348371.

Yoon, Y., Gürhan-Canli, Z., \& Schwarz, N. (2006). The effect of corporate social responsibility (CSR) activities on companies with bad reputations. Journal of consumer psychology, 16(4), 377-390. 
